\title{
Antibiotic Susceptibility Pattern of Extended-Spectrum Beta-Lactamase-Producing Klebsiella Pneumoniae and Escherichia Coli
}

\author{
Erlina Wahyu Elmawati ${ }^{1}$, Dewi Indah Noviana Pratiwi ${ }^{2}$, Noor Muthmainah ${ }^{3}$, Agung Biworo ${ }^{4}$ \\ ${ }^{1}$ Faculty of Medicine, Lambung Mangkurat University, Banjarmasin, Indonesia. E-mail: erlinawahyu99@gmail.com \\ ${ }^{2}$ Department of Clinical Pathology, Faculty of Medicine, Lambung Mangkurat University, Banjarmasin, Indonesia \\ ${ }^{3}$ Department of Microbiology, Faculty of Medicine, Lambung Mangkurat University, Banjarmasin, Indonesia \\ ${ }^{4}$ Department of Pharmacology, Faculty of Medicine, Lambung Mangkurat University, Banjarmasin, Indonesia
}

\begin{abstract}
Extended-Spectrum Beta-Lactamase (ESBL) producing bacteria is a type of resistance that leads to complex management of patients in intensive care due to their resistance to first, second, and third-generation Cephalosporin and monobactam antibiotics. The most ESBL-producing bacteria are found in the family Enterobacteriaceae, especially Klebsiella pneumoniae and Escherichia coli. The purpose of this research was to determine the sensitivity pattern of ESBLproducing bacteria in Intensive Care Units (ICUs) of Ulin Hospital, Banjarmasin, in the period of 2016-2018. This research was a descriptive study with a cross-sectional approach using data from the laboratory medical records of patients with positive ESBL in the ICUs of Ulin Hospital, Banjarmasin, between 2016 and 2018. The research sample was taken by the total sampling method. This research obtained 216 isolates of ESBL-producing bacteria consisting of 155 (71.8\%) isolates of Klebsiella pneumoniae and 61 (28.2\%) Escherichia coli. It was found that the Cephalosporin antibiotics (Cefazolin, Ceftazidime, Ceftriaxone, and Cefepime) and monobactam antibiotic (Aztreonam) had the lowest sensitivity. Aminoglycoside antibiotics (Amikacin), Carbapenem (Ertapenem and Meropenem), and Tetracycline (Tigesycline) were the most sensitive antibiotics. It was concluded that both Klebsiella pneumoniae and Escherichia coli were the most dominant ESBL-producing bacteria and showed good sensitivity to the Amikacin, Ertapenem, Meropenem, and Tigecycline.
\end{abstract}

Keywords: Extended-spectrum beta-lactamase, Klebsiella pneumoniae, Escherichia coli, antibiotics susceptibility pattern, intensive care units

\section{INTRODUCTION}

Nosocomial infections, also known as Hospital-Acquired Infections (HAIs), are infections, which patients acquire since the first 48 hours of hospitalization. Infection can occur when the patient is being hospitalized or within 30 days of the hospital discharge. ${ }^{1}$

The Intensive Care Unit (ICU) is a unit in the hospital specialized for patients with a high risk of HAIs. Both the ICU and Neonatal Intensive Care Unit (NICU) are part of the intensive care unit with staff and special equipment to support the observation and treatment of the patient whose potentially life-threatening conditions with an uncertain prognosis. Several factors such as a patient's low immune system, invasive monitoring of the patient's condition, exposure to various types of antibiotics, excessive use of antibiotics, and colonization by resistant bacteria can lead patients treated in ICU to a more tremendous potential for infection. ${ }^{2}$
Gram-negative bacteria, especially the Enterobacteriaceae family, become the most common cause of HAIs. Irrational use of antibiotics can cause mutations of Multidrug-Resistant Bacteria (MDR). Patients with MDR bacterial infections require more complex treatment than those with common bacterial infections because of the fewer drug choices and the higher dosage that can be used as a treatment for the patient's disease. Bacteria mostly cause Multidrug-resistant bacteria with the ability to produce enzymes that can hydrolyze beta-lactam antibiotics. This enzyme can hydrolyze Penicillin, first, second, and third generation of Cephalosporin and Monobactam antibiotics, and can be inhibited by Clavulanic acid and Carbapenem. Therefore, it is known as ESBL due to its broader resistance compared to other beta-lactamases-producing bacterial strains. Its resistance to various types of beta-lactam antibiotics makes the antibiotics not effective as a treatment. Extended-spectrum beta-lactamase is commonly 
produced by Gram-negative bacteria, especially by the Enterobacteriaceae family, which is a cause of infection in the ICU and NICU in developing countries. $^{3-7}$

Klebsiella pneumoniae and Escherichia coli are the most common ESBL-producing bacteria. Research on bacterial patterns in the ICU of Dr. Wahidin Sudirohusodo Hospital, Makasar, found that Klebsiella pneumoniae was the most prevalent bacteria (28.3\%). Study in the ICU of Cipto Mangunkusumo Hospital in Jakarta, which aimed to determine the phenotypic characteristics of the Enterobacteriaceae family of Gram-negative bacteria, showed that Klebsiella pneumoniae was the most isolated bacteria ( 61 out of 112 isolates). ${ }^{2}$

As a major teaching hospital and the only tertiary hospital in South Kalimantan, ICU and NICU of Ulin General Hospital, Banjarmasin are always crowded with patients from various cities year-round, making both units an ideal location for bacterial growth and infections not only for patients but also visitors and workers in the units. In addition to the emergence of ESBL-producing bacteria, the everyday use of antibiotics without any prescription in the community raises concerns about antibiotic resistance and treatment failure. This fact had led authors to perform research that aimed to determine the sensitivity patterns of ESBL-producing bacteria in the ICU at Ulin General Hospital, Banjarmasin.

\section{METHODS}

This research was a retrospective descriptive study by taking data from patients' medical records with positive ESBL results of specimen culture in the ICU of Ulin General Hospital, Banjarmasin, in 2016-2018.

The population in this study was all patients treated in the ICU and NICU of Ulin General Hospital, Banjarmasin in 2016-2018, including medical records of all patients specimen culture and antibiotic sensitivity testing at the Clinical Pathology Laboratory of Ulin General Hospital, Banjarmasin. The research sample was taken from the medical record data of the Clinical Pathology Laboratory of Ulin Hospital, Banjarmasin, by the total sampling method.

The research instrument used in this study was the medical record, the results of specimen culture (blood, urine, pus, sputum, and other body fluids), and antibiotic sensitivity testing of all patients treated in the ICU at the Ulin General Hospital, Banjarmasin from 2016 to 2018. The data were tabulated using Microsoft Excel 2010 and presented using frequency distribution table and percentage as the result of the study. The Ethical Committee of the Medical Faculty of Lambung Mangkurat University and Ulin General Hospital, Banjarmasin, approved the study protocol No. 444/KEPK-FK UNLAM/EC/IX/2019 and No. 210/VIII-Reg Riset/RSUDU/19, respectively.

\section{RESULTS AND DISCUSSIONS}

The results of this study performed in October-November 2019 found that of 9.333 culture requests in the Clinical Pathology Laboratory of Ulin Hospital, Banjarmasin from 2016 to 2018, 3.763 $(40.3 \%)$ isolates showed positive bacterial results. Positive culture results of patients in the ICU were 1.178 isolates, which consisted of 745 (63.2\%) positive isolates from the ICU and 433 (36.8\%) positive isolates from the NICU. The study also found that positive culture results of Klebsiella pneumoniae and Escherichia coli bacteria in ICU were 301 isolates. Thus, a total of 207 (68.8\%) and 94 isolates (31.2\%) were identified as Klebsiella pneumoniae and Escherichia coli.

Table 1 shows a higher percentage of ESBL-producing than non-ESBL-producing Klebsiella pneumoniae and Escherichia coli. The result of this research was consistent with research by Anong et al. at the Buddhachinaraj Hospital in Phitnasulok, Thailand, showing that 134 (62.3\%) of 250 isolates were ESBL (+). The high number of ESBL-producing bacteria might be caused by several factors, such as exposure to various types of antibiotics and excessive use of antibiotics that trigger bacterial mutations into new strains of bacteria. The low immune system of patients in the ICU and NICU also results in susceptibility to infection. ${ }^{8}$

The results showed that most ESBL-producing (+) bacteria were Klebsiella pneumoniae. A study by $n$ Taslim et al. in the ICU of Cipto Mangunkusumo Hospital also showed that Klebsiella pneumoniae was the most ESBL-producing bacteria as many as 61 (54.46\%) of 112 isolates. This study was different from research by Bindu et al. in several hospitals in India that found Escherichia coli as the dominant bacteria, as many as 346 (41.4\%) of 582 isolates. The number was less compared to the literature suggesting that Gram-negative bacteria such as Klebsiella pneumoniae and Escherichia coli are the most bacteria, which mutate into ESBL-producing bacteria. ${ }^{2,9}$ 
Nagarajan et al., in their research conducted at the Department of Microbiology, Allagapa University, mentioned that differences in the number of dominant bacteria could be due to differences in geography, hospital conditions, and different patient conditions. A closer similarity of conditions will lead to a more relative similarity of the bacterial pattern. Differences in the types of dominant microorganisms can also affect therapy or antibiotics as the primary therapeutic line. Irrational use of antibiotics can be one of the factors that cause the emergence of resistant bacteria. Proper administration of antibiotics should be begun with empirical antibiotics for patients who have bacterial infections without knowing the type of bacteria that infects them. Empirical antibiotics can be given for 48-72 hours while waiting for the results of laboratory tests. Administration of empirical therapy can be replaced by definitive treatment following the infecting bacterial strain. ${ }^{10}$

The study results showed that the positive culture results of the ESBL-producing Klebsiella pneumoniae were mostly derived from sputum specimens of patients in the ICU (Table 2). The results of this study were consistent with research by Sinanjung et al. in the ICU of Dr. Soeradji Tirtonegoro Hospital at Klaten in 2019. The research found that the most ESBL-producing Klebsiella pneumoniae originate from sputum specimens in 36 (40.45\%) of the total 89 isolates. The presence of bacteria in the results of sputum specimen culture can indicate an infection in the airways. ${ }^{11}$

Taslim et al., in their study, mentioned that one of the respiratory tract diseases with the highest incidence in the ICU is Ventilator-Associated Pneumonia (VAP). This disease is the most common type of nosocomial infection in ICU patients assisted with mechanical ventilation, using either endotracheal tubes or tracheostomy tubes. Klebsiella pneumoniae is a normal flora of the trachea and is a significant cause of pneumonia. The bacterial colonization of Klebsiella pneumoniae can cause the infection due to decreased immune system of patients treated in the ICU. Research by Luyt et al. in one of the hospitals in Paris in 2018 mentioned that risk factors for colonization of bacteria to cause VAP

Table 1. Distribution of K.pneumoniae and E.coli in ICUs of Ulin General Hospital in a period of 2016-2018

\begin{tabular}{lcccc}
\hline \multirow{2}{*}{ Isolates } & \multicolumn{2}{c}{ ICU } & \multicolumn{3}{c}{ NICU } \\
\cline { 2 - 5 } & $\mathrm{N}$ & $\%$ & $\mathrm{n}$ & $\%$ \\
\hline ESBL-producing K.pneumoniae & 106 & 73.6 & 49 & 77.7 \\
ESBL-non-producing K.pneumoniae & 38 & 26.4 & 14 & 22.2 \\
Total & 144 & 100 & 63 & 100 \\
ESBL-producing E.coli & 56 & 67.5 & 5 & 45.5 \\
ESBL-non-producing E. coli & 27 & 32.5 & 6 & 54.5 \\
Total & 83 & 100 & 11 & 100 \\
\hline
\end{tabular}

Table 2. Distribution of Klebsiella pneumoniae ESBL-producing bacteria according to specimen culture in the ICUs of Ulin General Hospital 2016-2018

\begin{tabular}{|c|c|c|c|c|c|}
\hline \multirow{2}{*}{ Bacteria } & \multirow{2}{*}{ Specimen } & \multicolumn{2}{|c|}{ Room } & \multirow{2}{*}{$\mathbf{n}$} & \multirow{2}{*}{$\%$} \\
\hline & & ICU & NICU & & \\
\hline \multirow{6}{*}{$\begin{array}{l}\text { Klebsiella } \\
\text { pneumoniae }\end{array}$} & Blood & 9 & 47 & 56 & 36.2 \\
\hline & Urine & 6 & 0 & 6 & 3.9 \\
\hline & Sputum & 76 & 0 & 76 & 49.0 \\
\hline & Pus & 11 & 2 & 13 & 8.3 \\
\hline & Other body fluids & 4 & 0 & 4 & 2.6 \\
\hline & Total & 106 & 49 & 155 & 100 \\
\hline \multirow{6}{*}{ Escherichia coli } & Blood & 18 & 5 & 23 & 37.7 \\
\hline & Urine & 8 & 0 & 8 & 13.1 \\
\hline & Sputum & 9 & 0 & 9 & 14.8 \\
\hline & Pus & 13 & 0 & 13 & 21.3 \\
\hline & Other body fluids & 7 & 1 & 8 & 13.1 \\
\hline & Total & 55 & 6 & 61 & 100 \\
\hline
\end{tabular}


is the length of use of ventilators and the low immune state of patients. A study by Sansom on ICU patients using a ventilator at a Thai Hospital also showed the same type of bacteria in the oropharynx and the bacteria that cause VAP. This research showed that bacterial colonization in the oropharyngeal due to poor oral hygiene of the patients could also extend to the airways and cause VAP. ${ }^{12,13}$

The results showed that the most positive culture results of ESBL-producing Escherichia coli were from blood specimens of patients in the ICU and NICU rooms (Table 2). The results of this study indicated similarities to previous studies conducted by Tsai et al., which showed that the most Escherichia coli ESBL-producing bacteria were found in the blood specimens of patients treated in the NICU room. Positive culture results of ESBL-producing bacteria in blood specimens in the NICU room can indicate the presence of Bloodstream Infection (BSI) caused by bacteria or commonly refer to as bacteremia.

Escherichia coli in newborns can be due to a urinary tract infection from the baby's mother during the birth process. Factors such as low immune system in infants, low birth weight, and antibiotic exposure, especially third-generation Cephalosporin to infants while being treated in the NICU room, can also cause bacteremia in infants treated in the NICU room. ${ }^{4}$

The number of positive ESBL-producing Escherichia coliculture results in the blood specimen culture of ICU room patients can also be related. Based on research conducted by the European Center for Disease Prevention and Control, $48.3 \%$ of cases of bacteremia were associated with the use of catheters, $32.6 \%$ are due to secondary infections, and $19.1 \%$ were due to unknown causes. Secondary infections developed from primary infection sites in the lungs (47.5\%), gastrointestinal (17.2\%), urinary tract $(18.6 \%)$, surgical wounds $(2.7 \%)$, skin and soft tissue (5.2\%), and other body parts (5.2\%). ${ }^{14}$

The results showed that Klebsiella pneumoniae and Escherichia coli had the lowest sensitivity to Cephalosporin (Cefazolin, Cefepime, Cefazolin, Ceftazidime, and (eftriaxone) and Monobactam (Aztreonam) antibiotics from year to year (Figure 1-4). This result was consistent with the theory suggesting that ESBL-producing bacteria are resistant to beta-lactam antibiotics, especially Cephalosporin and Monobactam. ${ }^{15}$

Extended-spectrum beta-lactamase-producing bacteria resistance to antibiotics is caused by increased enzymatic activity in hydrolyzing beta-lactam antibiotics. Beta-lactamase enzymes produced by bacteria hydrolyze the beta-lactam ring possessed by most beta-lactam antibiotics, making antibiotics fail to bind to transpeptidase in bacterial walls. Resistance certainly has a significant influence in determining the therapy of the disease because Cephalosporin antibiotics are commonly used in hospitals. Resistance to Cephalosporin-class antibiotics results in the increasingly narrow choice of antibiotics that can be used in patients. ${ }^{6,16}$

This study also found that Amikacin, Ertapenem, Meropenem, and Tigecycline had good sensitivity for bacterial infection caused by Klebsiella pneumoniae and Escherichia coli in ICU from 2016-2018. This finding was consistent with research conducted by

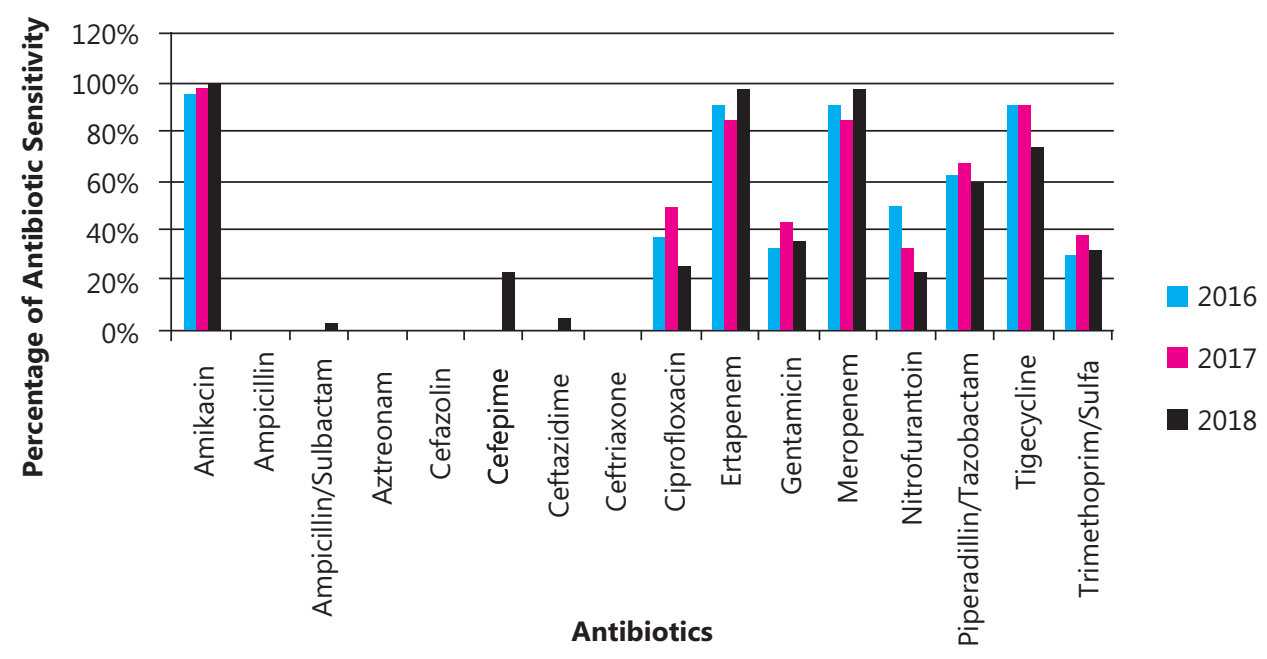

Figure 1. Sensitivity pattern of ESBL-producing Klebsiella pneumoniae in the ICU room at Ulin General Hospital in the period of 2016-2018 


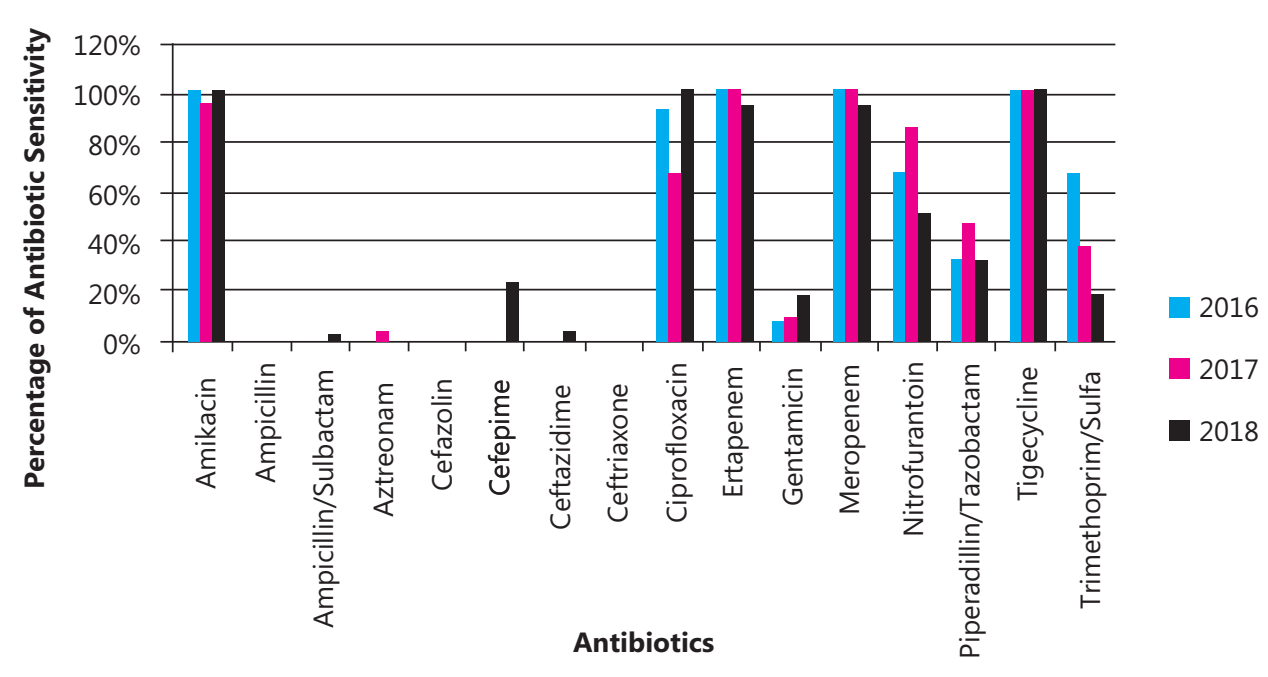

Figure 2. Sensitivity pattern of ESBL-producing Klebsiella pneumoniae in the NICU room at Ulin General Hospital, Banjarmasin in the period of 2016-2018

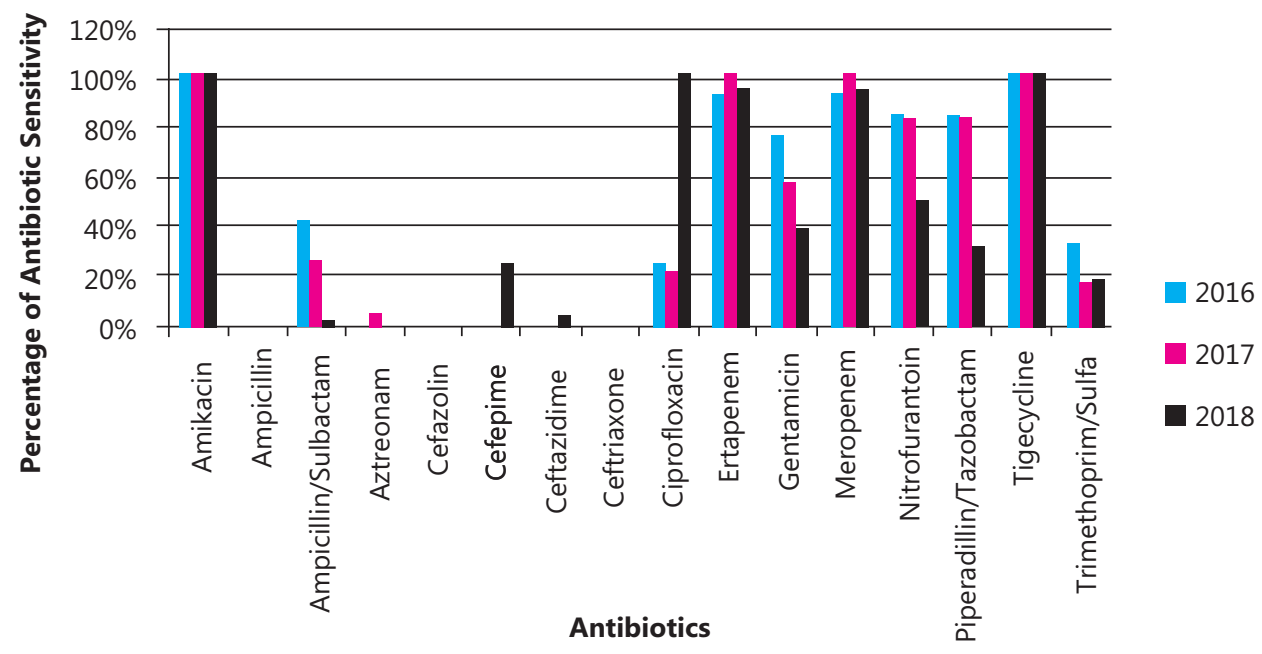

Figure 3. Sensitivity pattern of ESBL-producing Escherichia coli in the ICU room at Ulin General Hospital, in the period of 2016-2018

Sinanjung et al. in 2018 in the ICU room of Dr. Soeradji Tintonegoro General Hospital, which showed a $>80 \%$ sensitivity on antibiotics such as Amikacin and Meropenem. The results of the study of Klebsiella pneumoniae bacteria in the NICU room and Escherichia coli bacteria in the ICU room showed an increased sensitivity in $2018{ }^{11}$

The use of certain types of antibiotics that are rare in the case of infection in the ICU room is one factor influencing the enhanced antibiotic sensitivity. Cephalosporin-class antibiotics are often used as the first-line management of bacterial infection, cause resistance of bacteria due to continued exposure to the same antibiotics. Research conducted by Fauziyah et al. at ICU Fatmawati Hospital in 2011 showed a significant relationship between the intensity of antibiotics given as a treatment with bacterial sensitivity. This study indicated that the continuous use of certain antibiotics in a certain period could increase bacterial resistance to these antibiotics. ${ }^{11,17}$

Carbapenem-class antibiotics such as Ertapenem and Meropenem are not hydrolyzed by the beta-lactamase enzyme, enabling them to have good sensitivity to the ESBL-producing bacteria. This is because the Carbapenem antibiotic group has a slightly different beta-lactam ring from the Penicillin and Cephalosporin groups. Therefore, it is not easily hydrolyzed by the beta-lactamase enzyme. ${ }^{10}$ 


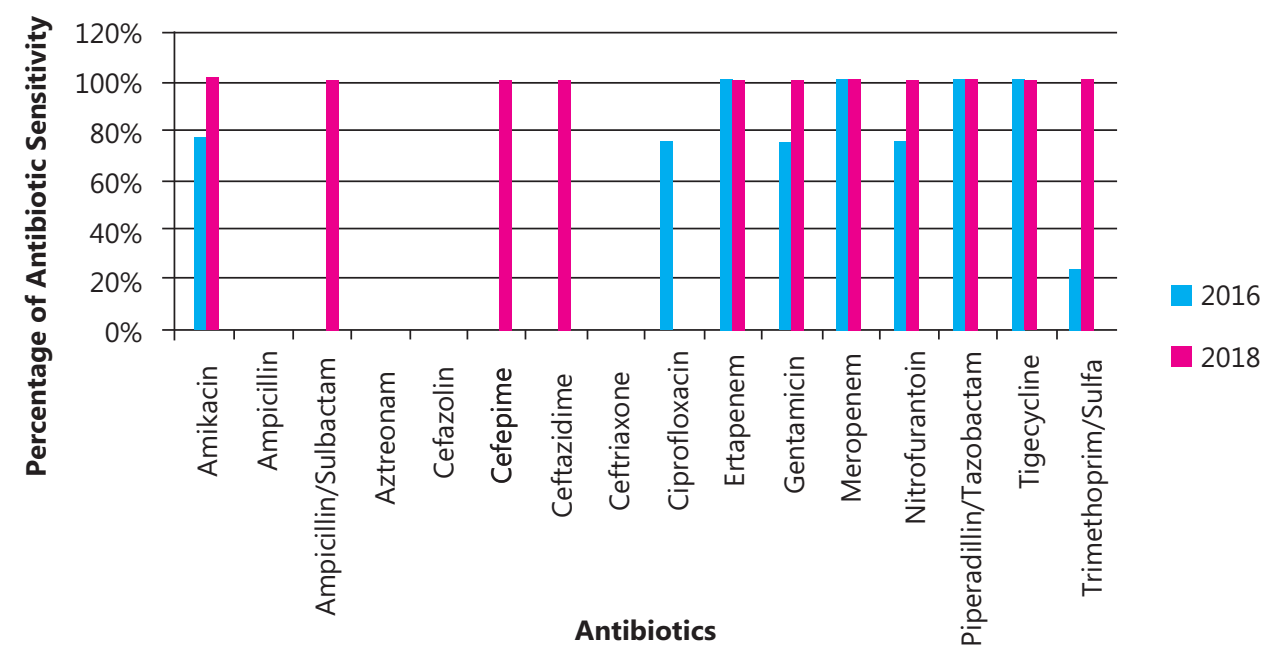

Figure 4. Sensitivity pattern of ESBL-producing Escherichia coli in the NICU room at Ulin General, Hospital in the period of 2016-2018

\section{CONCLUSIONS AND SUGGESTIONS}

The study made several conclusions. First, the sensitivity pattern of the ESBL-producing Klebsiella pneumoniae and Escherichia coli in the ICU in 2016-2018 showed a consistent resistance to the Cephalosporin (Cefazolin, Ceftazidime, Ceftriaxone, and Cefepime) and Monobactam (Aztreonam). Second, antibiotics that were still effectively used in treating patients infected with ESBL-producing bacteria in the ICU of Ulin Hospital, Banjarmasin in 2016-2018 were Amikacin, Ertapenem, Meropenem, and Tigecycline because due to their excellent sensitivity.

The pattern of bacterial sensitivity to antibiotics is a dynamic phenomenon that similar studies need to be conducted every year. In future studies, it was recommended to include the results of clinical diagnosis from the patient's medical record to obtain bacterial sensitivity patterns based on the type of disease.

The results of this study can be used as a reference for rational selection of antibiotics in the treatment of patients treated in intensive care to reduce the risk of antibiotic resistance. Furthermore, reasonable antibiotic selection can also increase the effectiveness and efficiency of antibiotic use, especially in patients in the ICU of Ulin General Hospital, Banjarmasin.

\section{REFERENCES}

1. Khan HA, Baig FK, Mehboob R. Nosocomial infections: epidemiology, prevention, control dan surveillance. Asian Pac J Trop Biomed, 2017; 7(5): 478-9.

2. Taslim, Emilzon, Tinni T. Maskoen. Pola kuman terbanyak sebagai agen penyebab infeksi di intensive care unit pada beberapa rumah sakit di Indonesia. Perdatin, 2016; 34: 57-8.

3. Kambuno, Norma Tiku, Dicky Fanggidae. Identifikasi bakteri Gram-negatif galur extended-spectrum beta-lactamase pada ruang NICU RSUD Prof. DR. W. Z. Johannes Kupang. JIK, 2017; 15: 334-341.

4. Tsai MH, Chu SM, Hsu JF, Lien R, Huang HR, et al. Risk factors and outcomes for multidrug-resistant Gram-negative bacteremia in the NICU. Pediatrics, 2014; 133(2): 324-6.

5. Folgore L, Bielicki J, Heath PT, Sharland M. Antimicrobial-resistant Gram-negative infections in neonates: Burden of disease and challenges in treatment. Curr Opin Infect Dis, 2017; 30: 2-3.

6. Anggraini D, Uswatun HS, Maya S, Fauzia AD, Dino I, Ruza PR. Prevalensi dan pola sensitivitas enterobacteriaceae penghasil ESBL di RSUD Arifin Achmad Pekanbaru. JKB, 2017; 30(1): 48.

7. Muhajir, Ahmad Siddiq, Priyo Budi Purwono, Samsriyaningsih Handayani. Gambaran terapi luaran infeksi saluran kemih oleh bakteri penghasil extended- spectrum beta-lactamase pada anak di RSUD Dr. Soetomo Surabaya. Sari Pediatri, 2016; 18(2): 112-4.

8. Kiddie A, Assawatheptawee K, Na-udom A, Boonsawang P. Risk factor for extended-spectrum beta-lactamase-producing Enterobacteriaceae carriage inpatient admitted to intensive care unit in a tertiary care hospital in Thailand. MDR, 2019: 1-3.

9. Bindu MH, Kasturi T, Reddy M, Indu K. Prevalence of ESBL Production in Escherichia coli and Klebsiella spp. from different clinical samples-A study in a teaching hospital in Telangana, India. IJCMAS, 2015; 4(3): 236-7.

10. Padmini N, Ajilda AAK, Sivakumar N, Selvakumar G. Extended-spectrum beta-lactamase-producing Escherichia coli and Klebsiella pneumoniae: Critical tools for antibiotic resistance pattern. J Basic Microbiol, 2017; 57: 464-5. 
11. Sinanjung K, Aman AT, Nirwati H. Proporsi Klebsiella pneumoniae isolat klinik penghasil Extended-Spectrum Beta Lactamase (ESBL) beserta pola kepekaannya terhadap antibiotika di RSUP Dr. Soeradji Tirtonegoro Klaten. Yogyakarta, Fakultas Kedokteran Universitas Gadjah Mada, 2019. (Tesis).

12. Luyt $C E$, Hékimian G, Koulenti D, Chastre J. Microbial cause of ICU-acquired pneumonia: Hospital-acquired pneumonia versus ventilator-associated pneumonia. Curr Opin Crit Care, 2018; 24(5): 333-334.

13. Sansom D, Merchant AT, Wara-Aswapati N, Ruaisungnoen W, Pitiphat W. Oral health and ventilator-associated pneumonia among critically ill patients: A prospective study. Oral Dis, 2016; 22(7): 709-14.

14. European Centre for Disease Prevention and Control. Introduction to the annual epidemiological report for
2015. In: ECDC. Annual epidemiological report for 2015. Stockholm, ECDC, 2017. Available from: https://ecdc.europa.eu/en/publications-data/ healthcare-associated-infections-acquired-intensive -care-units-annual (accessed 9 November, 2018).

15. Carrol KC, Hobden JA, Mietzner T, Miller S. Jawetz, Melnick, and Adelberg's Medical Microbiology. $27^{\text {th }}$ Ed., New York, McGraw-Hill Education, 2016; 383-7.

16. Sah SK, Hemalatha S. Extended-Spectrum Beta-Lactamase (ESBL) mechanism of antibiotic resistance and epidemiology. Int. J PharmTech Research, 2015; 7(2): 304.

17. Fauziyah, Siti, Maksum Radji, Nurgani A. Hubungan penggunaan antibiotika pada terapi empiris dengan kepekaan bakteri di ICU RSUP Fatmawati Jakarta. JFI, 2011; 5(3): 158. 